\title{
Dynamics and Activity of Iron-Reducing Bacterial Populations in a West African Rice Paddy Soil under Subsurface Drainage: Case Study of Kamboinse in Burkina Faso
}

\author{
Cécile Harmonie Otoidobiga1 ${ }^{*}$, Amadou Keita², Hamma Yacouba², Alfred S. Traore1, \\ Dayéri Dianou ${ }^{3}$ \\ ${ }^{1}$ Research Center for Biological, Alimentary and Nutritional Sciences, Research and Training Unit, Life and Earth \\ Sciences, University of Ouagadougou, Ouagadougou, Burkina Faso \\ ${ }^{2}$ International Institute for Water and Environmental Engineering, Ouagadougou, Burkina Faso \\ ${ }^{3}$ National Center for Sciences and Technology Research, Ouagadougou, Burkina Faso \\ Email: ${ }^{*}$ Cecile.otoidobiga@univ-ouaga.bf
}

Received 22 July 2015; accepted 24 August 2015; published 27 August 2015

Copyright (C) 2015 by authors and Scientific Research Publishing Inc.

This work is licensed under the Creative Commons Attribution International License (CC BY). http://creativecommons.org/licenses/by/4.0/

cC) (i) Open Access

\section{Abstract}

Iron toxicity is one of the main edaphic constraints that hamper rice production in West African savanna and forest lowlands. Although chemical reduction processes of various types of pedogenic iron oxides could not be underestimated, the bulk of these processes can be ascribed to the specific activity of Iron-Reducing Bacteria (IRB). The reducing conditions of waterlogged lowland soils boost iron toxicity through the reduction of almost all iron into ferrous form $\left(\mathrm{Fe}^{2+}\right)$, which can cause disorder in rice plant and crop yield losses. Aiming to contribute at the improvement of rice yield in Africa, an experiment was developed to evaluate the impact of subsurface drainage on IRB dynamics and activity during rice cultivation. Twelve concrete microplots with a clay-loam soil and a rice variety susceptible to iron toxicity (FKR 19) were used for the experiment. Soil in microplots was drained for 7 days (P1), 14 days (P2), and 21 days (P3), respectively. Control (T) microplots without drainage were prepared similarly. The evolution of IRB populations and the content of ferrous iron in the paddy soil and in soil near rice root were monitored throughout the cultural cycle using MPN and colorimetric methods, respectively. Data obtained were analyzed in relation to drainage frequency, rice growth stage, and rice yield using the Student $t$ test and XLSTAT 7.5.2 statistical software. From the results obtained, the subsurface drainage reduced significantly IRB populations $(p=0.024)$. However, the drainage did not affect significantly ferrous iron concentration in the soil near rice roots $(p=0.708)$. The concentration of ferrous iron $(p<$

${ }^{*}$ Corresponding author.

How to cite this paper: Otoidobiga, C.H., Keita, A., Yacouba, H., Traore, A.S. and Dianou, D. (2015) Dynamics and Activity of Iron-Reducing Bacterial Populations in a West African Rice Paddy Soil under Subsurface Drainage: Case Study of Kamboinse in Burkina Faso. Agricultural Sciences, 6, 860-869. http://dx.doi.org/10.4236/as.2015.68083 
$0.0001)$ in soil near rice roots and the number of IRB $(p<0.0001)$ were significantly higher during the rice tillering and maturity stages. Although no significant difference was observed for rice yield among treatments $(p=0.209)$, the $P 2$ subsurface drainage showed the highest yield and the lowest concentration of ferrous iron in soil near rice roots.

\section{Keywords}

Iron-Reducing Bacteria, Rice, Iron Toxicity, Subsurface Drainage

\section{Introduction}

Iron $(\mathrm{Fe})$ toxicity is a nutritional disorder associated with high iron concentrations in the soil solution that affects rice plant in lowland [1] [2]. Large concentrations of ferrous Fe in soil solution may occur either when Fe is mobilized in situ by microbial reduction of ferric Fe [3] or when reduced Fe is translocated into valley bottoms by interflow or subsurface flow from adjacent slopes [4]. Iron toxicity affects more than $50 \%$ of lowlands in West Africa [1] [5]. In Burkina Faso, many lowland crop fields were even abandoned due to iron toxicity [1] [6].

Iron toxicity is associated with large concentrations of reduced iron $\left(\mathrm{Fe}^{2+}\right)$ in the soil solution. As soon as a soil becomes flooded, the dissolved oxygen is consumed by aerobic bacteria and hemical oxidation reactions. Oxygen is depleted fast in most regions of the soil and alternative electron acceptors are used [7]. In anoxic conditions, Fe (III)-compounds are reduced and it results in ferrous ions production. This reduction of Fe(III) is largely controlled by microbial processes, and coupled to the oxidation of organic matter to support growth [8]. The appearance of iron toxicity symptoms in rice involves an excessive uptake of $\mathrm{Fe}^{2+}$ by the rice roots and its acropetal translocation into the leaves. A high production of toxic oxygen radicals can damage cell structural components and impair physiological processes [9] [10]. Excessive amounts of iron in the soil in reduced conditions upset the nutrient balance in plants [11]. Besides standard symptoms, i.e. browning and yellowing of leaves [9], iron toxicity can cause a 10\% - 100\% crop yield losses [5] [12].

The occurrence of Fe toxicity in flooded soils is often associated with poor drainage, poor nutrient status, acid $\mathrm{pH}$ reactions, and a low cation-exchange capacity of the soil [2] [13].

Indeed, the poor level of development of lowlands in West Africa, epitomized with bad water management, generates favorable conditions for the occurrence of iron toxicity [14]-[16]. Thus, areas subjected to iron toxicity generally have drainage problems, and certain management practices, i.e. periodic soil drainage which allows oxidation of the root zone, can reduce iron toxicity for plant [17] [18].

To contribute to the general effort to improve rice yield in Africa for food security, the present experiment was developed to measure the effect of subsurface drainage on microbiological and chemical parameters sustaining iron toxicity in paddy fields and on rice yield. To eliminate excess iron in soil through water management, concrete microplots were constructed, filled with a clay-loam soil and water was drained periodically during rice cultivation. The iron-reducing bacterial (IRB) populations' density and $\mathrm{Fe}^{2+}$ content in the paddy soil were monitored during the cultural cycle.

\section{Materials and Methods}

\subsection{Sampling Site}

The site for experiments was located at Kamboinse in the central plateau of Burkina Faso $\left(12^{\circ} 26^{\prime} 48^{\prime \prime} \mathrm{N}\right.$ and $\left.1^{\circ} 33^{\prime} 45 \mathrm{WW}\right)$. Experiments were performed on the experimental site of the International Institute for Water and Environmental Engineering (2iE) from August to December 2011. Physical and chemical properties of the soil collected from Kamboinse, are presented in Table 1. The soil studied had clay-loam texture, a high content of sulfates and iron, had a low organic matter content and wasn't deficient in crop nutrients as $\mathrm{N}, \mathrm{K}$ and $\mathrm{Mg}$.

\subsection{Microplots Experiments}

Twelve microplots of $1.50 \mathrm{~m} \times 1.20 \mathrm{~m} \times 1.20 \mathrm{~m}$ in size (total internal volume: $1.31 \mathrm{~m}^{3}$ ) were constructed in reinforced concrete to prevent cracks due to temperature changes following the alternation of the rainy and the 
dry seasons [19]. At the bottom of each microplot (1.45 m depth), perforated PVC pipes were installed and connected to an external tap through the concrete wall to sub-drain the soil (Figure 1). The design intended to improve circulation of water and oxygen within the rice root zone. Microplots were filled with the clay-loam soil described above, then flooded for 1 week. After the flooding period, two 15-day-old plants of FKR 19 rice (6 - 7 tons/ha of potential yield), developed by the Institute for Environment and Agricultural Research (INERA) from Oryza sativa rice, were transplanted at $20 \mathrm{~cm}$ hill intervals. Then, the soil was continuously flooded until rice maturity and harvest. Three replications and four modes of drainage were performed throughout the study: without drainage (control: T) and drainage for 7 days (P1), 14 days (P2) and 21 days (P3), respectively by regulating the drained water flow from the bottom tap (Figure 1). Chemical fertilizers (NPK and urea) were applied in the microplots according to the recommended doses of $300 \mathrm{~kg} / \mathrm{ha}$ of N-P-K (14-23-14) and 100 $150 \mathrm{~kg} / \mathrm{ha}$ of urea [20] [21].

\subsection{Enumeration of Iron-Reducing Bacterial Populations}

Iron-Reducing Bacteria (IRB) numbers were determined by the most-probable-number (MPN) method.

Medium for enumeration: The basal medium for enumeration was adapted from Hammann and Ottow [22] and consisted of the following components (per liter of distilled water): Glucose (20 g), Sodium acetate (5 g), $\mathrm{MgSO}_{4} \cdot 7 \mathrm{H}_{2} \mathrm{O}$ (0.05 g), $\mathrm{K}_{2} \mathrm{HPO}_{4}(0.25 \mathrm{~g}), \mathrm{KH}_{2} \mathrm{PO}_{4}(0.25 \mathrm{~g}), \mathrm{NaCl}(0.05 \mathrm{~g}), \mathrm{Na}_{2} \mathrm{MoO}_{4} \cdot 2 \mathrm{H}_{2} \mathrm{O}$ (0.005 g), $\mathrm{CaCO}_{3}(5$ g), $\mathrm{Fe}_{2} \mathrm{O}_{3}(1 \mathrm{~g})$. The $\mathrm{pH}$ was adjusted to 7.2 by addition of $\mathrm{NaOH}$ before $9 \mathrm{ml}$ were dispensed into $34 \mathrm{ml}$ Hungate tubes. The tubes were then autoclaved at $121^{\circ} \mathrm{C}$ for $15 \mathrm{~min}$.

Soil dilution and enumeration conditions: Soil $(0-15 \mathrm{~cm})$ samples were collected before transplanting and near rice hills after transplanting with a small corer and immediately introduced into air-free $10 \mathrm{ml}$ Veinoject tubes. Tubes were carried to the laboratory and kept at $4^{\circ} \mathrm{C}$ until bacterial enumeration. Soil $(5 \mathrm{~g})$ from tubes was ground using a sterilized pestle and mortar and suspended in $45 \mathrm{ml}$ sterile $0.5 \%$ (w/v) $\mathrm{MgCl}_{2}, 6 \mathrm{H}_{2} \mathrm{O}$ solution. One milliliter of the mixed soil suspension was placed into $9 \mathrm{ml}$ sterile $0.5 \% \mathrm{MgCl}_{2} \cdot 6 \mathrm{H}_{2} \mathrm{O}$ solution in Hungate tubes and diluted successively to $10^{-9}$ diluted suspension. One milliliter of the $10^{-1}$ to $10^{-9}$ fold diluted suspen-

Table 1. Physico-chemical characteristics of Kamboinse soil.

\begin{tabular}{ccccccccccccc}
\hline $\begin{array}{c}\text { Gravel } \\
(\%)\end{array}$ & $\begin{array}{c}\text { Sand } \\
(\%)\end{array}$ & $\begin{array}{c}\text { Loam } \\
(\%)\end{array}$ & $\begin{array}{c}\text { Clay } \\
(\%)\end{array}$ & $\begin{array}{c}\text { MO } \\
(\%)\end{array}$ & $\begin{array}{c}\text { Total C } \\
(\%)\end{array}$ & $\begin{array}{c}\text { Total } \mathbf{N} \\
(\%)\end{array}$ & $\mathbf{C} / \mathbf{N}$ & $\begin{array}{c}\mathbf{K} \\
(\mathbf{p p m})\end{array}$ & $\begin{array}{c}\mathbf{F e}_{\mathbf{t}} \\
(\mathbf{g} / \mathbf{K g})\end{array}$ & $\begin{array}{c}\mathbf{S O}_{4} \\
(\mathbf{p p m})\end{array}$ & $\begin{array}{c}\mathbf{M g} \\
(\mathbf{p p m})\end{array}$ & $\mathbf{p H} \mathbf{H}_{\mathrm{H}_{2} \mathrm{O}}$ \\
\hline 34 & 34 & 10 & 22 & 1.945 & 1.128 & 0.105 & 11 & 2520 & 14.51 & 118.81 & 681.52 & 6.52 \\
\hline
\end{tabular}

MO, Organic matter; Fe, total amount of Fe.

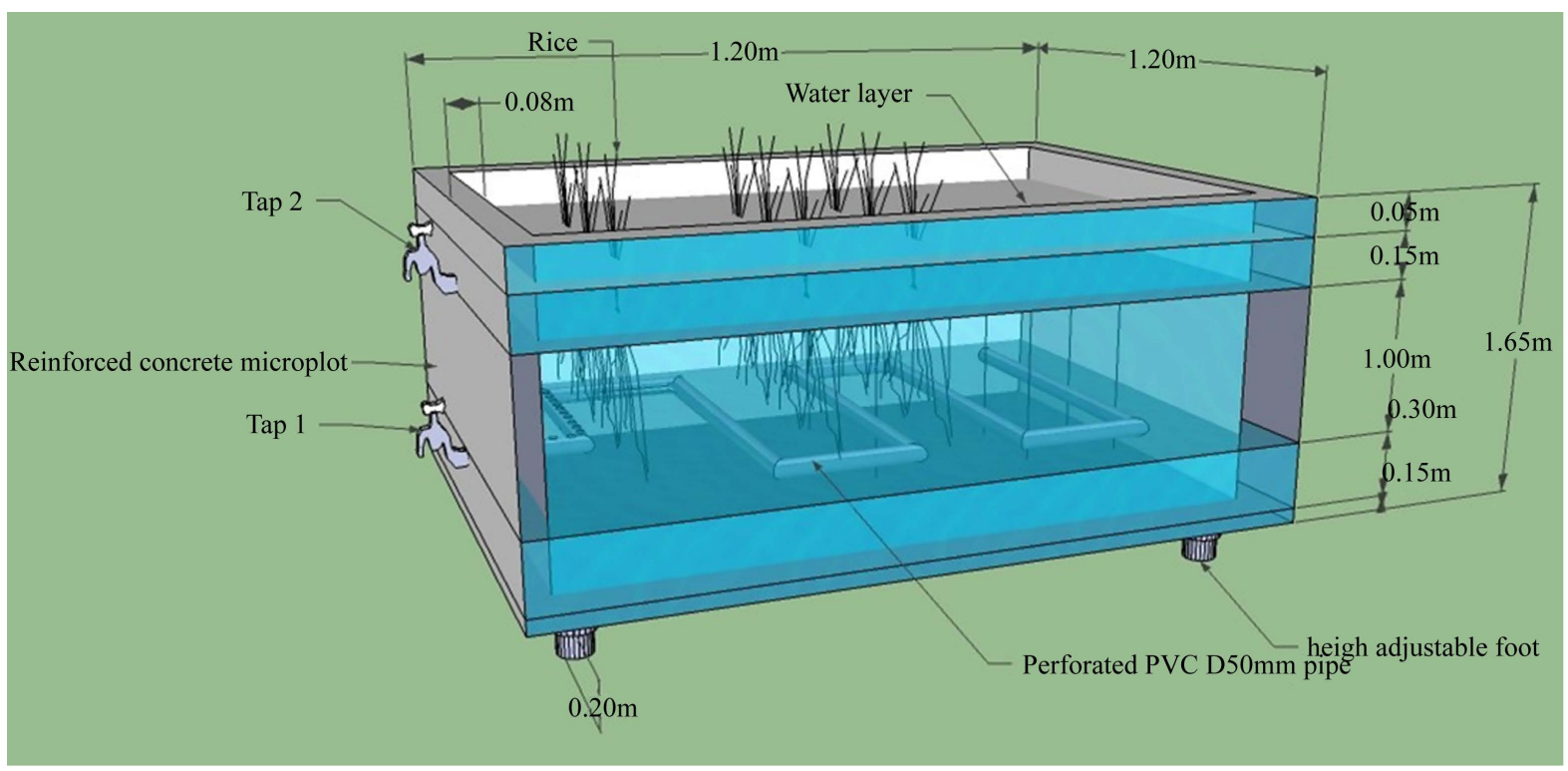

Figure 1. Microplots design for the experiments [19]. 
sion was inoculated to $9 \mathrm{ml}$ of the basal medium for enumeration in Hungate tubes. Three tubes per dilution were used. Tubes were incubated at $30^{\circ} \mathrm{C}$ in the dark for 5 days, then immediately analyzed for $\mathrm{Fe}^{2+}$ after addition of $0.2 \%$ ortho-phenantroline and $10 \%$ acetic acid according to Prade [23]. Positive tubes sustaining the reduction of $\mathrm{Fe}^{3+}\left(\mathrm{Fe}_{2} \mathrm{O}_{3}\right)$ into $\mathrm{Fe}^{2+}$ (reddish coloration) were revealed by measuring optical density at $510 \mathrm{~nm}$ using a spectrophotometer. The MPN number of IRB was determined using a MPN table for three tubes according to Hugues and Plantat [24]. Bacterial enumeration was performed before flooding when the soil was dried, on transplanting day (1 week after flooding) and during the rice growth stages until harvest near rice hills.

\subsection{Determination of Ferrous Iron Content in Soil}

From the soil sampled for bacterial enumeration and at the same periods during the rice cultural cycle, Vizier [25] method was used to measure the content of ferrous iron in the soil solution, using $0.2 \%$ ortho-phenantroline and $10 \%$ acetic acid reagents as described above.

\subsection{Statistical Analysis}

Data obtained were analyzed for IRB populations' development and activity, drainage mode, rice growth stage and rice yield variations using the Student's t-test and XLSTAT 7.5.2 statistical software. Mean parameters were compared according to the Newman Keuls' test at 5\% probability level.

\section{Results and Discussion}

\subsection{Effect of Soil Moisture on IRB Populations Dynamic and Ferrous Iron Content in Soil near Rice Roots}

Densities of IRB enumerated on soil before flooding, when the soil was dried and on soil near rice roots during the rice growth stages, are shown in Figure 2 and expressed as $\log _{10}$ (most probable population number $\mathrm{g}^{-1}$ dry soil). The number of IRB in the soil near rice roots increased after one week of flooding for all microplots (Figure 2). An increase in IRB population number of $124.63 \%$, 40.89\%, 52.84\% and 98.92\% was recorded in

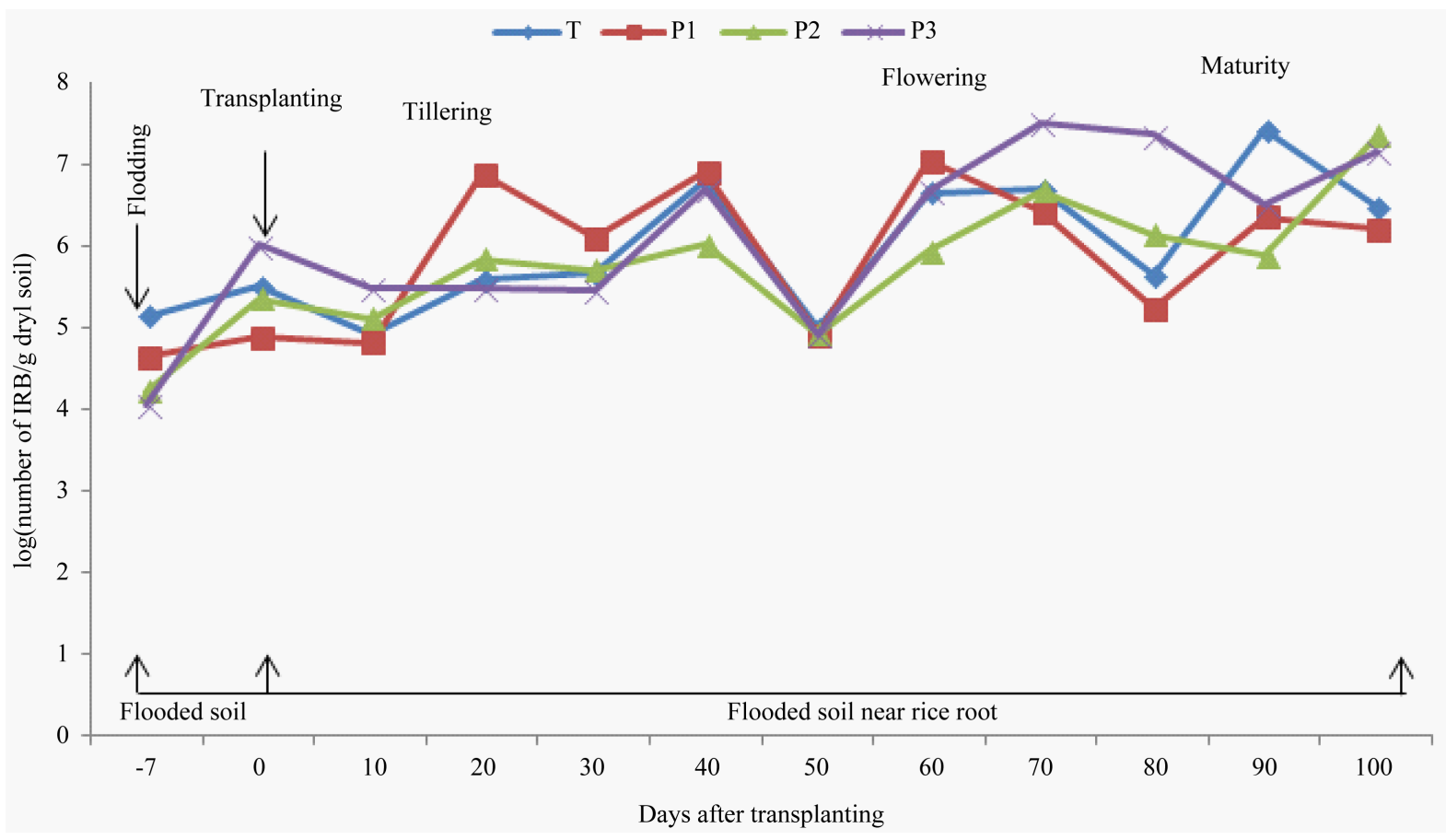

Figure 2. Densities of Iron-Reducing Bacteria in soil before flooding, at transplanting day, and in soil near rice roots during the cultural cycle of FKR 19 rice in microplots without drainage (T), and drained for 7 days (P1), 14 days (P2) and 21 days (P3), respectively (means of 3 replicates). 
the soil of the control (T), P1, P2, and P3 drained microplots, respectively. Hammann and Ottow [22] reported that soon as a soil is flooded or submerged by stagnant water, the reductive processes start [26] [27]. During the process, oxygen is consumed by soil respiration (bacteria and fungi mainly) and a large amounts of mineral elements as Fe III and nutriments were released in the soil solution [28]. In these conditions Fe III was used as electron acceptor by IRB, for anaerobic respiration coupled to organic compound biodegradation [7] [8] [29]-[31]. Our findings are in agreement with the results of Ouattara [6] which reported that lactate-utilizing IRB enumerated in Burkina Faso paddy soil (Kou Valley), ranged from $3.5 \times 10^{2}-7.3 \times 10^{2}$ cells/g dry soil before flooding to $2 \times$ $10^{4}-6 \times 10^{7}$ cells/g dry soil after flooding. As also underlined Jacq et al. [17] and Betremieux [32], the growth of Iron-Reducing Bacteria is stimulated by flooding.

$\mathrm{Fe}^{2+}$ content in soil before flooding when the soil was dried and in soil near rice roots during the rice growth stages, are shown in Figure 3 and expressed as $\log _{10}$ ( $\mu \mathrm{g} / \mathrm{g}$ dry soil). The concentration of ferrous iron increased after one week of flooding in the soil near rice roots for all microplots (Figure 3). After flooding, a concentration increase of 73.07, 31.9, 34 and 26.53\% was recorded in the soil of the control and in P1, P2, P3 drained microplots, respectively.

The concentration of ferrous iron increased after one week of flooding in the soil for all the microplots (Figure 3). This result is in agreement with the findings of Jacq et al. [17] and Betremieux [32] who reported the same increment of ferrous iron content in soil after the flooding of a Senegal paddy soil.

Iron toxicity only occurs in flooded soils and affects primarily the production of lowland rice [9] [11]. Cherif et al. [1] and Shahid et al. [11] underlined that the reducing conditions of waterlogged lowland soils boost iron toxicity through solubilization of almost all iron into its ferrous form $\left(\mathrm{Fe}^{2+}\right)$. After flooding, oxygen is depleted rapidly by the respiration of soil microorganisms [33]. With the depletion of oxygen, $\mathrm{Fe}^{3+}$ can act as electron acceptor for microbial respiration and sequentially become reduced. Within a few days after inundation or at a redox potential of $<180-150 \mathrm{mV}$, the reduction of $\mathrm{Fe}^{3+}$ begins [7] [17] [34].

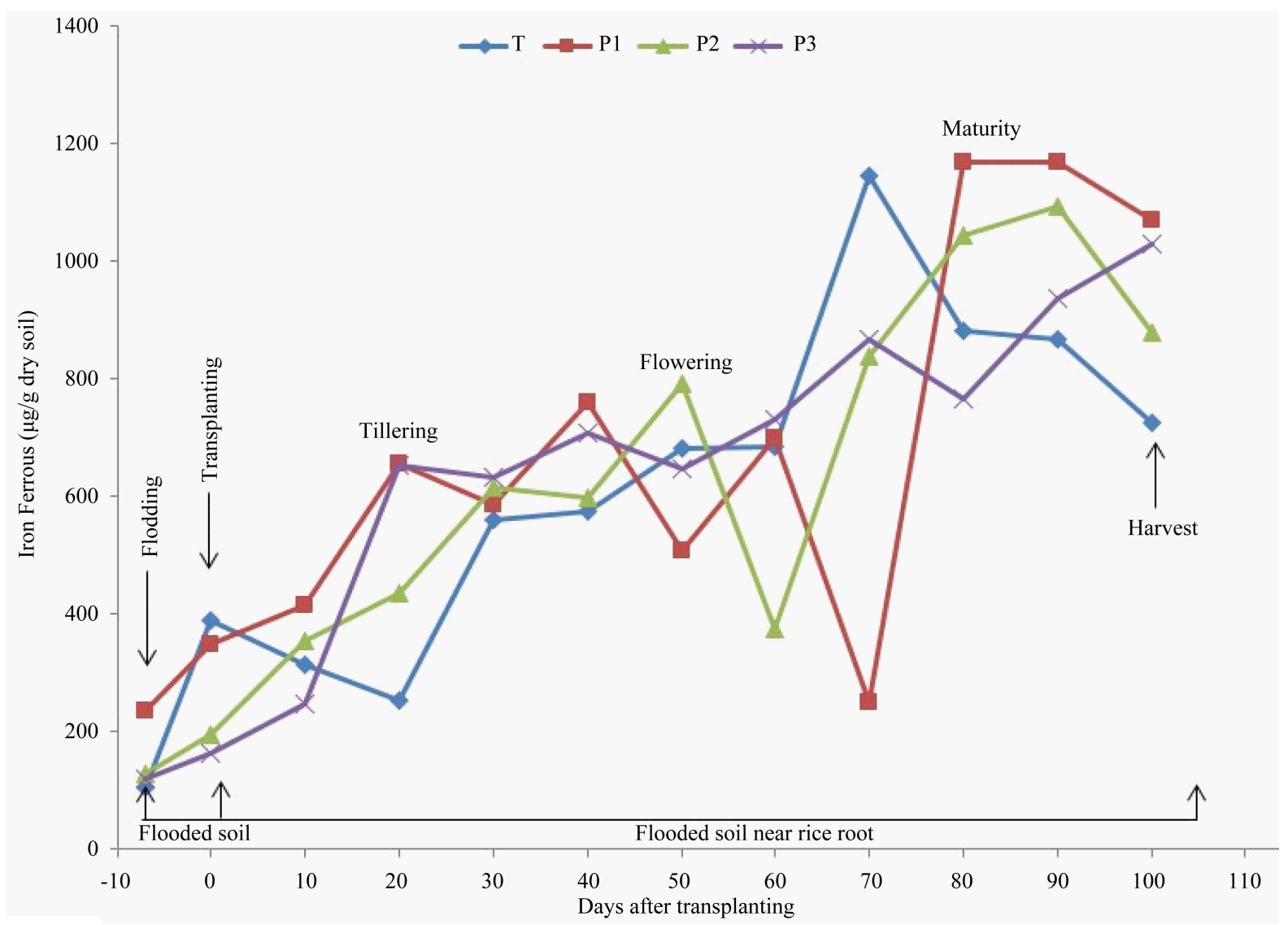

Figure 3. Evolution of the soil $\mathrm{Fe}^{2+}$ content during the cultural cycle of FKR 19 rice in microplots not drained (T), and drained for 7 days (P1), 14 days (P2) and 21 days (P3), respectively (means of 3 replicates). 


\subsection{Effects of Rice Plant on IRB Populations' Dynamic and Activity}

Jacq et al. [17], reported that the amount of ferrous iron in the soil solution of flooded soils are significantly higher in planted than in unplanted soil. In the present study, the number of IRB and ferrous iron content in soil near rice roots increased gradually with fluctuations from transplanting day to rice flowering and maturity stages in all the paddy microplots (Figure 2 \& Figure 3). In most microplots, the highest densities of IRB were recorded from rice tillering and flowering to maturity stages, at which bacterial population number could reach $10^{6}$ to $10^{7} / \mathrm{g}$ dry soil. The highest levels of ferrous iron in soil near rice roots were recorded also from rice tillering and flowering to maturity stages at which it could reach $10^{3}$ to $10^{4} \mu \mathrm{g} / \mathrm{g}$ dry soil. IRB population density and ferrous iron concentration in soil near rice roots appeared particularly high during the tillering and flowering to maturity stages of rice growth (Figure 2 \& Figure 3). Our results are in agreement with those obtained by Jacq et al. [17] who recorded also a similar evolution pattern of IRB population in Senegal paddy soils during rice cultural cycle. However, these findings are not in agreement with the results of Ouattara [6], who reported constant IRB populations in a rice paddy soil of Burkina Faso (Kou Valley) after 21 days of flooding. The high physiological activities of rice plant in tillering, flowering and maturity stages, may result in the production of more substrates available for bacterial growth [28]. These periods which correspond to the highest level of reduced soil condition may enhance the exudation of carbohydrates and other metabolites sustaining IRB population growth and ferrous iron highest content in soil [8] [17].

\subsection{Impact of Drainage on IRB Populations' Development and Activity}

The variance of IRB numbers in soil near rice roots, in relation to drainage and sampling period during rice growth is presented in Table 2. The Newman Keuls' test revealed that the number of bacteria in the paddy soil near rice roots was significantly related to drainage $(p=0.024)$, sampling period $(p<0.0001)$ and combined both factors ( $<<0.001$, Table 2). Throughout the experiment, the average number of IRB population in the soil of microplots decreased significantly $(\mathrm{p}=0.024)$ with drainage of water in P1 and P2 microplots, relatively to the control (T) and P3 ones (Table 3). The rate of decrease was 2.2\% and 3.24\% in P1 and P2 drained microplots relatively to the control, respectively. However, no significant difference was observed between IRB populations in the soil of $\mathrm{T}$ and P3 microplots (Table 3).

The variance of soil $\mathrm{Fe}^{2+}$ content in soil in relation to drainage and sampling period during rice growth is presented in Table 2. It appeared that drainage alone had no significant effect on the soil near rice roots ferrous

Table 2. Variance of IRB number and ferrous iron content in soil near rice roots in relation to drainage and sampling period during the cultural cycle of FKR 19 rice.

\begin{tabular}{cccccc}
\hline Source of variation & df & \multicolumn{2}{c}{$\log ($ IRB number/g dry soil) } & \multicolumn{2}{c}{ Fe II ( $\mu$ g/g dry soil) } \\
\hline & & F & p & F & p \\
\hline Drainage & 3 & 3.292 & $0.024^{*}$ & 0.464 & $0.708^{\mathrm{ns}}$ \\
Period & 11 & 22.153 & $<0.0001^{* *}$ & 21.759 & $<0.0001^{* *}$ \\
Drainage x Period & 33 & 2.249 & $0.001^{* *}$ & 1.935 & $0.007^{* *}$ \\
\hline
\end{tabular}

$\mathbf{d f}=$ degree of freedom; $\mathbf{F}=$ Fisher $\mathrm{F} ;{ }^{*}$ significant $\mathrm{p}<0.05 ;{ }^{* *}$ significant $\mathrm{p}<0.01 ;{ }^{\text {ns }}$ not significant $\mathrm{p}<0.05$.

Table 3. Effect of drainage on IRB population number in soil near rice roots during the cultural cycle of FKR 19 rice in microplots not drained (T), and drained for 7 days (P1), 14 days (P2) and 21 days (P3) (means of 3 replicates).

\begin{tabular}{ccc}
\hline Drainage & $\log ($ IRB number/g dry soil) & Fe II ( $\mu$ g/g dry soil) \\
\hline T & $5.867^{\mathrm{a}}$ & $597.989^{\mathrm{a}}$ \\
P1 & $5.630^{\mathrm{b}}$ & $655.012^{\mathrm{a}}$ \\
P2 & $5.570^{\mathrm{b}}$ & $625.588^{\mathrm{a}}$ \\
P3 & $5.957^{\mathrm{a}}$ & $624.462^{\mathrm{a}}$ \\
\hline
\end{tabular}

Means with a same letter within a column are not significantly different according to Newman Keuls’ test $\mathrm{p}<0.05$. 
iron content $(\mathrm{p}=0.708)$. However, the sampling period in relation to rice growth stage affected significantly the soil ferrous iron content $(\mathrm{p}<0.0001)$. The combined effects of drainage and sampling period also affected significantly $(p=0.007)$ the content of ferrous iron in soil near rice roots.

Ferrous iron content evolution in soil during the cultural cycle of rice appears similar for drained and not-drained microplots (Figure 3).

Most of the highly active Iron-Reducing Bacteria are anaerobe or facultative anaerobe. IRB are very efficient in anoxic conditions, and thus oxygenation reduces their growth [17]. However, the IRB population number in the soil of the P3 drained microplots increased slightly (1.01\%) indicating that some among the IRB population can survive and grow in aerobic compartments in the presence of low pressure of oxygen where a surplus of oxygen is released by healthy roots [17] [23].

Survival of IRB populations and ferrous iron production in drained microplots could be, also explained by heterogeneous distribution of oxygen through the drainage creating anoxic compartments. A lack of oxygenation of these microsites in drained microplots promotes IRB population survival [7] and ferrous iron production [3]. An efficient oxygenation of soil near rice roots by water drainage would significantly reduce anaerobic IRB population's activity.

\subsection{Impact of Drainage on FKR 19 Rice Yield}

Becker and Folkard [9] and Shahid et al. [11] reported that symptoms of iron toxicity in rice result from excessive uptake of ferrous ions by the roots and their acropetal translocation through xylem outflow to the aerial parts. According to these authors, the typical symptoms linked to this are the bronzing or yellowing processes of the leaves [9] [11]. In the present study, symptoms of rice iron toxicity weren't observed in all the microplots. One raison may be the FKR 19 rice variety is not susceptible to iron toxicity as reported some studies [19]. As also reported Keita [19], even the oxygenation in the root zone was not enough to prevent the growth of Iron-Reducing Bacteria and the ferrous iron concentration, it did help in increasing the soil pH (from 5.7 to 7.3) which will limit the absorption of ferrous iron by the rice and thus, improve rice yield [11] [35]. Rice plants can develop also physiological avoidance and/or tolerance mechanisms [7] [36] [37] to survive under Fe-toxic condition such as: oxidation of ferrous iron at the root surface (Fe-oxidizing power) [38], exclusion of Fe at the root surface (Fe-excluding power) [39] [40], retention of Fe in the root tissue (Fe-retaining power) [39] [40] or leaf tissue tolerance to excess amounts of Fe [41].

Chemical fertilizers (NPK and urea) application in microplots may also explain these results [11]. Many studies reported that amendment of paddy soil in mineral element may reduce symptoms of iron toxicity for rice [37] [42] [43]. In fact, iron toxicity is also defined as a multiple nutritive disorder further increased by mineral deficiencies through excesses of $\mathrm{H}_{2} \mathrm{~S}$ [13] [44] [45]. Deficiencies in minerals may enlarge the root permeability that enhances exudation, oxygen-consumption and iron-reduction, finally leading to severe iron toxicity [46][48].

In the present study, the symptoms of iron toxicity for rice plant were not observed according IRRI standard evaluation systems for rice [49] in all the microplots and no significant difference $(p=0.209)$ was found for rice yield among treatments. However, drained microplots, in particular P2 microplot, showed the highest yield (Figure 4). These results are in agreement with those of Keita [19] and Ethan et al. [45] which reported that drainage in iron-toxic soils increased grain yield of lowland rice by the reduction of ferrous iron absorption of rice plant. Indeed, in oxygenated rice soil, the greatest fraction of iron (II) is present in precipitated forms (ferrous iron inactive forms) as siderite [7] [45]. Soil oxygenation by water drainage affected also iron (II) profiles by iron (II) oxidization in a fast chemical and microbial reaction to iron (III) in zones where oxygen is present [7] $[50]$.

\section{Conclusion}

The study revealed that flooding decreases Iron-Reducing Bacteria population's number in soil near rice roots. Despite the aeration of paddy soil by drainage, IRB population's number and activities appeared to be modulated mainly by the physiological activity of rice plant. Thus, ferrous iron content and IRB number were high in soil near rice roots during tillering, flowering and maturity stages. IRB activity did not exhibit a deleterious effect on rice yield due probably to the soil quality, drainage, chemical fertilizers application in microplots (NPK and urea) and/or to the rice variety (FKR 19). Although, no significant difference was observed for rice yield among 


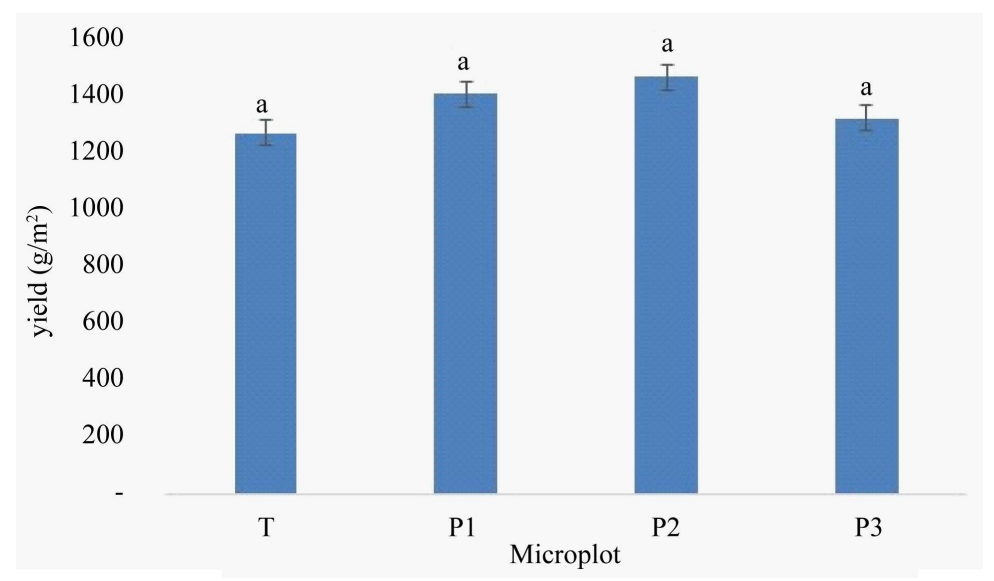

Figure 4. Yield of FKR 19 rice variety in microplots not drained $(\mathrm{T})$, and drained for 7 days (P1), 14 days (P2) and 21 days (P3) (means of 3 replicates). Yields sharing the same letter are not significantly different according to Newman Keuls' test $\mathrm{p}<0.05$.

drainage treatments, drained microplots showed the highest yields. Thus, an efficient oxygenation of soil by subdrainage may be a key factor for ferrous iron toxicity control in paddy field.

\section{Acknowledgements}

The authors would like to express profound gratitude to International Institute for Water and Environmental Engineering (2iE), CNRST/IRSS, International Foundation for Science, PACER-UEMOA/RABIOTECH, FCNWAAPP and CNS-FL/WAAPP, for financial and technical supports.

\section{References}

[1] Cherif, M., Audebert, A., Fofana, M. and Zouzou, M. (2009) Evaluation of Iron Toxicity on Lowland Irrigated Rice in West Africa. Tropicultura, 27, 88-92.

[2] Engel, K., Asch, F. and Becker, M. (2012) Classification of Rice Genotypes Based on Their Mechanisms of Adaptation to Iron Toxicity. Journal of Plant Nutrition and Soil Science, 175, 871-881. http://dx.doi.org/10.1002/jpln.201100421

[3] Ponnamperuma, F.N. (1972) The Chemistry of Submerged Soils. Advances in Agronomy, 24, 29-96. http://dx.doi.org/10.1016/S0065-2113(08)60633-1

[4] Sahrawat, K.L. and Diatta, S. (1995) Nutrient Management and Season Affect Soil Iron Toxicity. Annual Report 1994. West Africa Rice Development Association, Bouake, Ivoiry Coast, 34-35.

[5] WARDA (2002) Annual Report 2001-2002. Activity Highlights, ADRAO/WARDA., Bouake, Ivoiry Coast, 29-37.

[6] Ouattara, A.S. (1992) Contribution to the Study of Iron-Reducing Bacteria and Sulfate in Paddy Soils of the Kou Valley (Burkina Faso). Ph.D Dissertation, Provence University, Aix-Marseille I.

[7] Liesack, W., Shnell, S. and Revsbech, N.P. (2000) Microbiology of Flooded Rice Paddies. FEMS Microbiology Reviews, 24, 625-645.

[8] Yi, W., Wang, B. and Qu, D. (2012) Diversity of Isolates Performing Fe(III) Reduction from Paddy Soil Fed by Different Organic Carbon Sources. African Journal of Biotechnology, 11, 4407-4417.

[9] Becker, M. and Folkard, A. (2005) Iron Toxicity in Rice Conditions and Management Concepts. Journal of Plant Nutrition and Soil Science, 168, 558-573. http://dx.doi.org/10.1002/jpln.200520504

[10] Mongon, J., Konnerup, D., Colmer, T.D. and Rerkasem, B. (2014) Responses of Rice to Fe2+ in Aerated and Stagnant Conditions: Growth, Root Porosity and Radial Oxygen Loss Barrier. Functional Plant Biology, 41, 922-929. http://dx.doi.org/10.1071/FP13359

[11] Shahid, M., Nayak, K.A., Shukla, A.K., Tripathi, R., Kumar, A., Raja, R. Panda, B.B., Meher, J., Bhattacharyya, P. and Dash, D. (2014) Mitigation of Iron Toxicity and Iron, Zinc, and Manganese Nutrition of Wetland Rice Cultivars (Oryza sativa L.) Grown in Iron-Toxic Soil. Clean Soil, Air, Water, 42, 1604-1609. http://dx.doi.org/10.1002/clen.201300178 
[12] Paul, K., Diatta, M. and Millar, D. (Editors) (2010) The Effect of Iron Toxicity on the Yield and Yield Components of rice. Proceedings of Africa Rice Congress on Innovation and Partnerships to Realize Africa's Rice Potential, WARDA, IER, Bamako, 22-26 March 2010, 52-53. http://www.warda.cgiar.org/publications/ARC2010/ARC2010-Abstract.pdf

[13] Fageria, N.K., Santos, A.B., Barbosa, F.M.P. and Guimarães, C.M. (2008) Iron Toxicity in Lowland Rice. Journal of Plant Nutrition, 31, 1676-1697. http://dx.doi.org/10.1080/01904160802244902

[14] Kosaki, T. and Juo, A.S.R. (1986) Iron Toxicity in Inland Valleys: A Case Study from Nigeria. In: Juo, A.S.R. and Lowe, J.A., Eds., Wetlands and Rice in Sub-Saharan Africa Ibadan, IITA, Ibadan, 167-174.

[15] Okusami, T.A. (1986) Properties of Some Hydromorphic Soils in West Africa. In: Juo, E.S.R. and Lowe, J.A., Eds., Wetlands and Rice in Sub-Saharan Africa Ibadan, IITA, Ibadan, 167-179.

[16] Audebert, A. and Sahrawat, K.L. (2000) Mechanism for Iron Toxicity Tolerance in Lowland Rice. Journal of Plant Nutrition, 23, 1817-1885. http://dx.doi.org/10.1080/01904160009382150

[17] Jacq, V.A., Prade, K. and Ottow, J.G. (1991) Iron Sulphide Accumulation in the Rhizosphere of Wetland Rice (Oriza sativa L.) as the Result of Microbial Activities. In: Fyfe, W.S. Ed., Developments in Geochemistry, Vol. 6, Diversity of Environmental Biogeochemistry, Elsevier, Amsterdam, 453-468.

[18] Audebert, A. (2006) Diagnosis of Risk and Approaches to Iron Toxicity Management in Lowland Rice Farming. In: Audebert, A., Narteh, L.T., Kiepe, P., Millar, D. and Beks, B., Eds., Iron Toxicity in Rice-Based Systems in West Africa, ADRAO, Cotonou, 6-17.

[19] Keïta, A. (2015) Subsurface Drainage of Valley Bottom Irrigated Rice Schemes in Tropical Savannah: Case Studies of Tiefora and Moussodougou in Burkina Faso. PhD Thesis, Wageningen University, Delft.

[20] INERA (2000) Descriptive Folders of Rice Cultivars. Institute of Environment and Agricultural Research, Ouagadougou. http://www.inera.bf/

[21] Sokona, M.E.B., Boro, A., Hema, A. and Katiella, B. (2010) Diagnostic Study of the Rice Irrigation Scheme of Tiefora, Province of Comoe, Region of the Cascades. Field Report, 2iE, Ouagadougou.

[22] Hammann, R. and Ottow, J.C.G. (1974) Reductive Dissolution of $\mathrm{Fe}_{2} \mathrm{O}_{3}$ by Saccharolytic Clostridia and Bacillus polymyxa under Anaerobic Conditions. Journal of Plant Nutrition and Soil Science, 137, 108-115.

[23] Prade, K. (1987) Influence of Nutrient Supply to the Iron Poisoning of Paddy (O. Sativa L.) in the Basse Casamance Senegal. PhD Thesis, University of Hohenheim, Stuttgart. (In German)

[24] Hugues, B. and Plantat, J.L. (1983) Calculation of the Acceptable Limits of the Most Probable Number When the Number of Inoculum Per Dilution Is Important. Chemosphere, 12, 1679-1684. http://dx.doi.org/10.1016/0045-6535(83)90100-5

[25] Vizier, J.F. (1969) Selection and Development of a Method for Iron Ferrous Dosage in Waterlogged Soils. ORSTOM Books, Pedology Serial, Montpellier.

[26] Conrad, R. (2007) Microbial Ecology of Methanogens and Methanotrophs. Advances in Agronomy, 96, 1-63 http://dx.doi.org/10.1016/s0065-2113(07)96005-8

[27] Hori, T. Muller, A., Igarashi, Y., Conrad, R. and Friedrich, M.W. (2010) Identification of Iron-Reducing Microorganisms in Anoxic Rice Paddy Soil by 13C-Acetate Probing. The ISME Journal, 4, 267-278. http://dx.doi.org/10.1038/ismej.2009.100

[28] Bongoua, D.A.J. (2009) Iron-Reducing Bacterial Communities Implications and Environmental Settings in the Functioning and Rice Fields Soils Quality (Thaïlande and Ivoiry Coast). PhD Thesis, Henri Poincare University, Nancy.

[29] Berthelin, J. (1982) Microbial Processes in Hydromorphic Soils in Temperate Regions: Implications of Pedogenesis. Pedology Grand, 32, 313-328.

[30] Bousserrhine, N., Gasser, U.G., Jeanroy, E. and Berthelin, J. (1999) Bacterial and Chemical Reductive Dissolution of Mn-, Co-, Cr-, and Al-Substituted Goethites. Geomicrobiology Journal, 16, 245-258. http://dx.doi.org/10.1080/014904599270622

[31] Ehrlich, H.L. (2002) Geomicrobiology. 4th Edition, Marcel Dekker Publisher, New York.

[32] Betremieux, R. (1951) Experimental Study of Iron and Manganese in the Soils. Annales Agronomiques, 10, $193-295$.

[33] Prade, K., Ottow, J.C.G., Jacq, V.A., Malouf, G. and Loyer, J.Y. (1990) Relationships between the Properties of Flooded Rice Soils and Iron Toxicity in Lower Casamance (Senegal). Studies, Review and Summary of Previous Work. ORSTOM Books, Pedology Serial, IRD, Montpellier, 453-474.

[34] Patrick, J.W.H. and Reddy, C.N. (1978) Chemical Changes in Rice Soils. In: IRRI, Ed., Soils and Rice, The International Rice Research Institute, Manila, 361-379.

[35] Dave, G. (1985) The Influence of pH on the Toxicity of Aluminum, Cadmium, and Iron to Eggs and Larvae of the Zebrafish. Brachydanio Rerio Ecotoxicology and Environmental Safety, 10, 253-267. http://dx.doi.org/10.1016/0147-6513(85)90072-7 
[36] Nozoe, T., Agbisit, R., Fukuta, Y., Rodriguez, R. and Yanagihara, S. (2008) Characteristics of Iron Tolerant Rice Lines Developed at IRRI under Field Conditions. Japan Agricultural Research Quarterly, 42, 187-192. http://dx.doi.org/10.6090/jarq.42.187

[37] Sahrawat, K.L. (2010) Reducing Iron Toxicity in Lowland Rice with Tolerant Genotypes and Plant Nutrition. Plant Stress, 4, 70-75.

[38] Ando, T. (1983) Nature of Oxidizing Power of Rice Roots. Plant Soil, 72, 57-71. http://dx.doi.org/10.1007/BF02185094

[39] Tadano, T. (1975) Devices of Rice Roots to Tolerate High Iron Concentration in Growth Media. Japan Agricultural Research Quarterly, 9, 34-39.

[40] Tadano, T. (1976) Studies on the Methods to Prevent Iron Toxicity in Lowland Rice. Hokudai Nougakubu Houbun Kiyou (Mem. Fac. Agric. Hokkaido Univ.), 10, 22-68.

[41] Bienfait, H.F. (1989) Prevention of Stress in Iron Metabolism of Plants. Acta Botanica Neerlandica, 38, 105-129. http://dx.doi.org/10.1111/j.1438-8677.1989.tb02035.x

[42] Sahrawat, K.L. (2004) Iron Toxicity in Wetland Rice and the Role of Other Nutrients. Journal of Plant Nutrition, 27, 1471-1504. http://dx.doi.org/10.1081/PLN-200025869

[43] Panda, B.B., Sharma, S., Mohapatra, P.K. and Da, A. (2012) Application of Excess Nitrogen, Phosphorus, and Potassium Fertilizers Leads to Lowering of Grain Iron Content in High-Yielding Tropical Rice. Communications in Soil Science and Plant Analysis, 43, 2590-2602. http://dx.doi.org/10.1080/00103624.2012.716122

[44] Ottow, J.C.G., Prade, K., Bertenbreiter, W. and Jacq, V.A. (1993) Iron Toxicity Mechanisms of Flooded Rice (Oryza sativa L.) in Senegal and Indonesia. In: Raunet, M., Ed., Lowland and Rice-Growing, CIRAD-CA, Montpellier, 231241.

[45] Ethan, S., Odunze, A.C., Abu, S.T. and Iwuafor, E.N.O. (2011) Effect of Water Management and Nitrogen Rates on Iron Concentration and Yield in Lowland Rice. Agriculture and Biology Journal of North America, 2, 622-629. http://dx.doi.org/10.5251/abjna.2011.2.4.622.629

[46] Benckiser, G., Ottow, J.C.G., Watanabe, I. and Santiago, S. (1984) The Mechanism of Excessive Iron-Uptake (Iron Toxicity) of Wetland Rice. Journal of Plant Nutrition, 7, 177-185. http://dx.doi.org/10.1080/01904168409363184

[47] Benckiser, G., Santiago, S., Neue, H.U., Watanabe, I. and Ottow, J.C.G. (1984) Effect of Fertilization on Exudation, Dehydrogenase Activity, Iron-Reducing Populations and Fe (II) Formation in the Rhizosphere of Rice (Oryza sativa L.) in Relation to Iron Toxicity. Plant Soil, 79, 305-316. http://dx.doi.org/10.1007/BF02184324

[48] Prade, K., Ottow, J.C.G. and Jacq, V.A. (1988) Excessive Iron Uptake (Iron Toxicity) by Wetland Rice (O.su tiva L.) on an Acid Sulfate Soil in the Casamance/Senegal. In: Dost, H., Ed., Selected Papers of the Dakar Symposium on Acid Sulphate Soils, I.L.R.I., Wageningen, 150-162.

[49] IRRI (2002) Standard Evaluation System For Rice. International Rice Research Institute, Manila.

[50] Hauck, S., Benz, M., Brune, A. and Schink, B. (2001) Ferrous Iron Oxidation by Denitrifying Bacteria in Profundal Sediments of a Deep Lake (Lake Constance). FEMS Microbiology Ecology, 37, 127-134. http://dx.doi.org/10.1111/j.1574-6941.2001.tb00860.x

\section{Abbreviations}

IRB: Iron-Reducing Bacteria;

MPN: Most Probable Number;

INERA: Institute for Environment and Agricultural Research. 